\title{
The Heritage District of Malolos; Conserving Kamestizuhan Amidst the Threat of Commercialization
}

\author{
Dennis L. Estacio \\ dennis.estacio@bulsu.edu.ph \\ Bulacan State University, College of Architecture \& Fine Arts, Malolos City, Philippines \\ University of Santo Tomas, Samplaoc, Manila, Philippines
}

\begin{abstract}
Conservation as a concept and process has its fundamental objective, the protection of cultural property from loss and depletion. Implicit in this is the notion of maintaining living contact with the pass through the identification, transmission, and protection of that which is considered cultural valuable. Conservation of historic buildings and streets is growing rapidly in many countries, under the threat of commercialization. The historic district in Shanghai, China has been successful in transforming its traditional residential houses as well as its old factories, into a community for creative industry (Yung, 2011). This study will pursue the same objective by providing a conservation management plan to rescue Kamestizuhan, the Heritage District of Malolos, to withstand the effects of commercialization to urban morphology. To pursue the objective, the researcher conducted cultural documentation procedures. Archival resources were reviewed to establish the historical context. Pertinent documents were gathered and reviewed from the City Government of Malolos to identify the past and present plan of actions if there's any in safeguarding and preserving the heritage district. Records of socioeconomic profile of Malolos were also studied to determine the impact of commercialization in Kamestizuhan Heritage District. Politicians, local historians, academicians, conservation advocates and other stakeholders were interviewed and the results proved that there is no regulation or concrete policies being implemented strictly by the local government in order to safeguard and protect the Heritage District of Malolos Zones. With the use of the comparative historical method, local historic towns with successful conservation approach were compared to serve as guide in determining applicable considerations for the proposal. Photo-documentation, Mapping and inventory were used and findings reveal that some ancestral houses were demolished and sold as effect of commercialization. Surveys also shows that majority of the local has low level of awareness in the historical significance of Kamestizuhan. Ultimately, the study formulated policy in conserving the Kamestizuhan Heritage District of Malolos amidst commercialization.
\end{abstract}

Keywords: conservation, commercialization, cultural heritage, urban

\section{Introduction}

Historic towns are losing their identity and their historical value because of demolitions and transformations which often lead to irreversible cultural, historical, social change due to combined tourism development and commercialization. Many of these historic towns are at risk, threatened, physically degraded, damaged or destroyed as an aftermath of urban development (Martinez, 2006).

Cultural loss is man's problem nowadays. Many countries, provinces, and towns are developing physically. In the past, culture is one of the bases of the development in one's country. It also enhances the quality of living of every individual. But because of developments and commercialization, culture almost disappeared. Some of the technological innovations tend to transform traditional cultural system frequently with unexpected social 
consequences. Tourism and development in a culture-rich heritage like Vigan allows cultural heritage to flourish and be preserved, and in some cases the absence of regulatory practices gradually fade the cultural heritage in one's memory.

One example of these historic cities is the City of Malolos, a city rich in traditional culture one should be proud of, but because of modernization, it loses its cultural identity. Malolos was rich in cultural aspects like ancestral houses. The Filipino architects say that the ancestral houses represent the built manifestation of the Filipino aesthetics that hews to sociability, openness, and functionality although it was brought by the Spanish. The Bahay-na- Bato satisfies the needs of Filipinos and withstand the country's two seasons, wet and dry. Filipino architecture has always been "sustainable" and "environmentally-friendly" like the Bahay Kubo. Many heritage sites and structures also distinctively mirror the heart of Filipino architecture rich in culture in the City of Malolos.

The unregulated commercialization and sprawling urbanization in the area of Malolos threatens the Kamestizuhan Heritage District. The effort of this study in conserving the Kamestizuhan as Heritage District will establish connection of the past and the present.

\section{Methodology}

This chapter presents the research methods and techniques, the sample of the study, the research instruments, the data collection, and the data processing and statistical treatment used.

\section{Methods and Techniques of the Study}

The study utilized the quantitative and qualitative methods in order to complete the study. This research method used to record, describe and analyze data.

To pursue the objective, the researcher conducted cultural documentation procedures. Archival resources were reviewed to establish the historical context. Review of varied sources that dealt with the Bulacan Heritage.

Pertinent documents were gathered and reviewed from the City Government of Malolos to identify the past and present plan of actions if there's any in safeguarding and preserving the heritage district. Records of socioeconomic profile of Malolos were also studied to determine the impact of commercialization in Kamestizuhan Heritage District. Politicians, local historians, academicians, architects, businessmen, conservation advocates and other stakeholders were interviewed for the collaboration of triple helix approach in the conservation of Heritage District Zone of Malolos. With the use of the comparative historical method, local and international historic towns with successful and non-successful conservation approaches were compared to serve as guide in determining applicable considerations for the proposal.

Photo-documentation is used in order to assess the current physical conditions of the heritage structures within the area of Malolos. Pictures were taken from the outside into the inside of the selected structures. Each picture will be labelled properly. Data analysis of the commonality of details of the architectural structures through comparative approach will be done to isolate the factors of the significant and the common details and features of the significance architectural edifice. Mapping and inventory were used to be able to gather necessary data that can only be achieved through the conduct of mapping and inventory of all significant structures relevant to the study.

This study examined the level of awareness of the 100 respondents. The survey questionnaire and interview guide were devised based upon the criteria formulated by the researcher.

\section{Sample of the Study}

This study engaged the help of 100 respondents in terms of conservation management in Malolos heritage district represented by (10\%) Malolos City government officials, (10\%) cultural heritage advocates, $(10 \%)$ architects, $(40 \%)$ architecture students $(10 \%)$ heritage house owners and $(20 \%)$ of the local in the community. 


\section{Research Instruments}

The survey questionnaire and interview guide were utilized to gather relevant and pertinent data and information needed to answer the questions. The survey questionnaire was perceived and expressed by the respondents using a four-point likert scale.

\section{Data Gathering Procedures}

The researcher administered random survey and interview to the identified respondents represented by Malolos City government officials, cultural heritage advocates, architects, architecture students, heritage house owners and the local in the community.

\section{Data Processing and Statistical Treatment}

The duly checked/ validated/ and approved Interview guide questions and survey instruments by the researcher was utilized. The interview was conducted to the respondents. The survey forms were reproduced through photocopy and distributed to the 100 identified respondents in Malolos. Each respondent was given the copy of survey form, procedure in answering the instruments were explained to the respondents. After the Instruments were accomplished, all the survey forms were retrieved and gathered by the researcher. Majority of the factors was perceived and expressed by the respondents using the four-point Likert scale. After the questionnaires were gathered, they were sorted, tabulated and treated. Mean Scores were computed to describe the level of importance of the respondents on the Level of Awareness of the respondents.

\section{Results, Analysis and Discussion}

\section{A. Findings from Documentary Analysis}

\section{Malolos History}

From the ancient time, there was only Manila, Vigan, Malolos and Cebu for Chinese settled in the Philippines. The Parian of Malolos was established in 1755 and its residents are migrants from Manila's Parian (now Arroceros Park). Iloilo, has also Parian District, which is the present Malo, Iloilo. (The Malolos Heritage Town,2019)

\section{Pariancillo History}

Pariancillo has a glorious past. Its peculiar name rhymes with that of the Parian in Binondo across the Pasig River which is the oldest China town in the world. Pariancillo literally means a "small Parian" but actually derived from the Hokkien word "palien" that means "organization" or "federation" which is actually a generic term for all districts founded in different cabeceras during the Spanish Regime which served as a place where Chinese stayed and lived. These Chinese men married locals particularly those from the old nobilities or the maguinoo and produced half bred sons and daughters which later became an influential class in the 18th and 19th century Philippines. This we refer to the Mestizos Sangleys. (Tiongson, 2004). The sangleys of Malolos grew that way and had benefitted too to the central location of Malolos, at the crossroads of major destinations like Quingua, Baliwag, Calumpit, Bigaa and Hagonoy, Manila and San Fernando and via train, as far as Dagupan. They will build their bodegas and made it part of their bahay na bato where products from various places were stored before being sold. The big houses at Pariancillo were products of these particular centuries and therefore specimens of Philippine economic history. (Tiongson, 2004). 


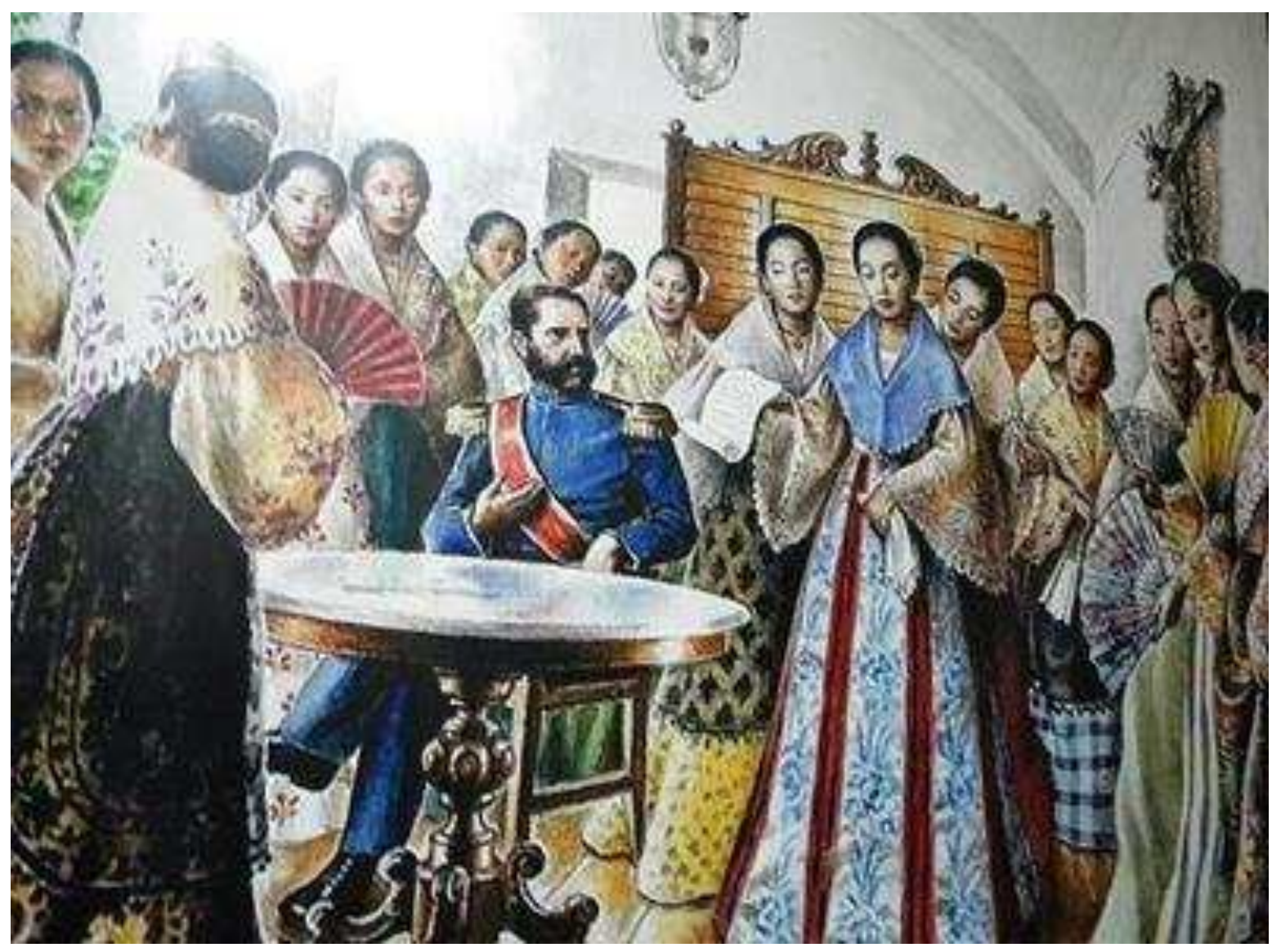

Fig. 1 The 21 Women of Malolos

Pariancillo became more important in Philippine history in the 19th century when their rise as an economic force equated to influence and power. As a testament, the young women of the district made the revolutionary request to the Spanish governor general regarding their eagerness to have education and learn the Spanish language. These women we knew today as the 21 women of Malolos to whom Jose Rizal wrote a letter as requested by Marcelo H. del Pilar.

At the height of the Philippine Revolution and the imminent threat of American colonialism, Pariancillo became a major bastion of Filipino revolutionary spirit. President Emilio Aguinaldo established his government center around Malolos, and the many bahay na bato of Pariancillo served as government offices, most prominent among the posts were that of Prime Minister Apolinario Mabini and Antonio Bautista, the aide de camp of Pres. Aguinaldo. (City of Malolos, webpage)

\section{Kamestizuhan District}

Kamestizuhan District of Malolos was originally called Pariancillo. It is the district intended for the Chinese residents of Malolos in 1700s. It is all started in 1755 when Governor General ordered the expulsion of chinese from the Philippines due to their participation in some rebellion and sedition against the Spanish Government. Some of them were transferred to Malolos at the time which was already a hub for some chinese and in able to be far from Spanish Government in Manila. When hearing about the migration, Governor General orders that the towns outside Manila should have a special district for them, thus the Malolos Pariancillo was established 
Pariancillo means "small parian". Upon the order there are provision for those chinese who resides in the town for the longest time that they will not be expelled if they married a native of Malolos and so the Sangleys of Malolos were born and the Pariancillo became the Chinese enclave in Bulacan Province. (City of Malolos, webpage).

\section{Bahay na Bato}

Pariancillo, if had been preserved matches that or even more superior than the Heritage City of Vigan. It has the same qualities of places like Taal in Batangas as well as Silay in Negros Occidental. The National Historical Institute has declared it once as a museum town. It boasts old houses that served as containers of lives and experiences and spaces of national and local histories. Pariancillo is full of architectural treasures crafted by the hands of the Filipino artists, masons, carpenters and artisans. (Parungao, 2003)

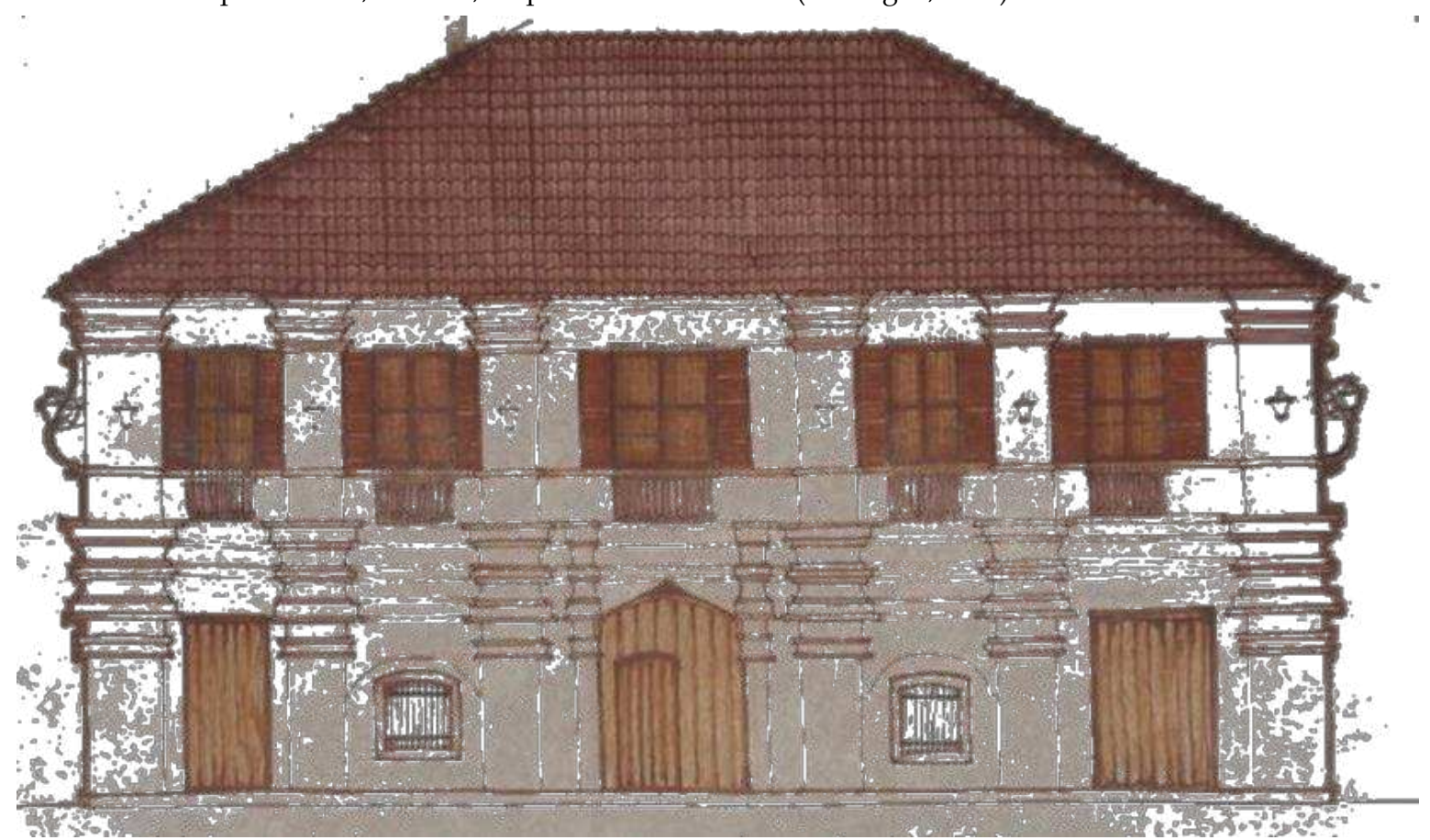

Figure 2. Typical Bahay-na-Bato.

The plans and components of the Bahay-na-Bato

The plans and components of the bahay na bato are tropical, practical and similar. They always have two floors. The main portal at the first floor leads to the adobe surrounded silong that served as storage of rice (bangan) or sometimes as entresuelo or additional work or living space in the house. (Tiongson, 2004). Almost always the houses have a place for the carro or processional floats of the santo under the care of the family which also served as a symbol of affluence and influence and catholic devotion and religiosity. At the upper floor, what would welcome guests is the big sala overlooking the outside streets with tall windows decorated with capiz shells and colorful glasses. These windows slide through the pasamano where under it are located the ventanillas or opening that let the outside air ventilate the tropical house. Also, at the second floor are the cuartos and the living quarters of the family usually having tall doors made of solid wood. Among the implements inside a common bahay na bato are the aparador, tocador and the lavadera. (Tiongson, 2004) 
Aside from the living quarters, a comedor can also be found which is always connected to the kusina. These kusinas are embellished with various implements like the pugon, paminggalan and banguera used to clean and dry the dishes. In the kusina is a storage room called dispensa. The toilet, the casilla or comun, is also a part of the house and sometimes freely standing beside the house. (Tiongson, 2004)

The bahay na bato in Malolos have azoteas or open-air balconies that overview the garden and the potted plants. Before, the roofs of the bahay na bato were made of nipa and tiles but today has been replaced with galvanized irons. (Tiongson, 2004) Fr. Alzina labelled the bahay na bato as arquitectura mestiza since it was born out of the fusion of indigenous architecture, Chinese craftsmanship and European styles. The materials are also a mix of wood and hard stones. (Parungao, 2003)

\section{Malolos to Vigan}

A world heritage wonder in Vigan City that Malolos could have. A never been told saddest story that many Bulakenyos should know. In 1998 President Joseph Estrada, issued a big budget and assigned Department of Tourism headed by Gemma Cruz-Araneta, offered Malolos LGU for the rehabilitation of Malolos Town Proper including all ancestral houses and structure within the Malolos Town Center (became a heritage zone in 2001). This offer aims to save historic ancestral houses that became "very first Offices during the First Republic" a

President's Gift for its legacy and that time it is the 100th Anniversary of First Republic. In able to acquire the offer then Mayor requested the Sanggunian to enact a resolution accepting the fund and after that DOT will give it to the LGU.

Tragic and turmoil time Malolos was marred by politics and trust issues at opposing parties at the government, the Cityhood issue, and they are all focused on the upcoming election. The council didn't make a resolution and the DOT turned it back the National Government for the year-end auditing of 1999. On the following year (2000) DOT diverted in Vigan and they accepted it, the Mayor and its municipal council thru a municipal resolution. What Malolos had failed Vigan has succeed. Thus, the Heritage City of Vigan was born, with government aid, collective efforts of people and love of heritage, the beautiful heritage houses and structure has revived making its way to UNESCO inclusion and finally into a World Heritage Cities. Although, Malolos is now a protected zone (a declared Heritage Town in 2001). Many of its ancestral houses was torn down between 1998 to 2001 making its number reduced. Sad but True Malolos sacrificing too much because of politics. (Joaquin Sy, 2014). Excerpt from the article of Joaquin Sy (The Malolos Heritage Town, March 12, 2014).

\section{B. Findings from Interviews}

The past local government officials believe that heritage conservation is not the solution to alleviate poverty in the city of Malolos, instead it will just require large amount of money for the awareness campaign to safeguard the heritage structures. (Ar. Parungao, 2020). There are only two ordinances related to heritage preservation that were passed by the local government up to this point in time.

The Department of Education (Malolos) believed that it is costly to launch and support the heritage awareness campaign of Malolos. It will require large amount of money to finance the project and agency to budget the awareness campaign (Ar. Parungao, 2020).

The 3rd and 4th generation of the owners of the heritage structures has no personal memories and attachment to the old structures drive them to sell the property they inherited. (Ar. Martinez, 2020/ Mayor Gatchalian, 2020). 
The absence of guidelines and IRR also lead to the toothless two (2) ordinances resulting to the impeding commercialization of Uitangcoy House for hotel use, and the Old Cartel now use as station of tricycles.

\section{Findings from Comparative Analysis}

With the use of the comparative method, the local historical towns with successful and non-successful conservation approaches were compared to serve as guide in analysis, using the factor in terms of awareness, community involvement, local ordinances, existing guidelines and implementing rules and regulations. The Heritage Conservation Management status of Malolos, Silay, Iloilo, and Vigan were compared and analyzed.

\section{Comparative Analysis: Local Conservation Management}

Table No. 1 Comparative Analysis

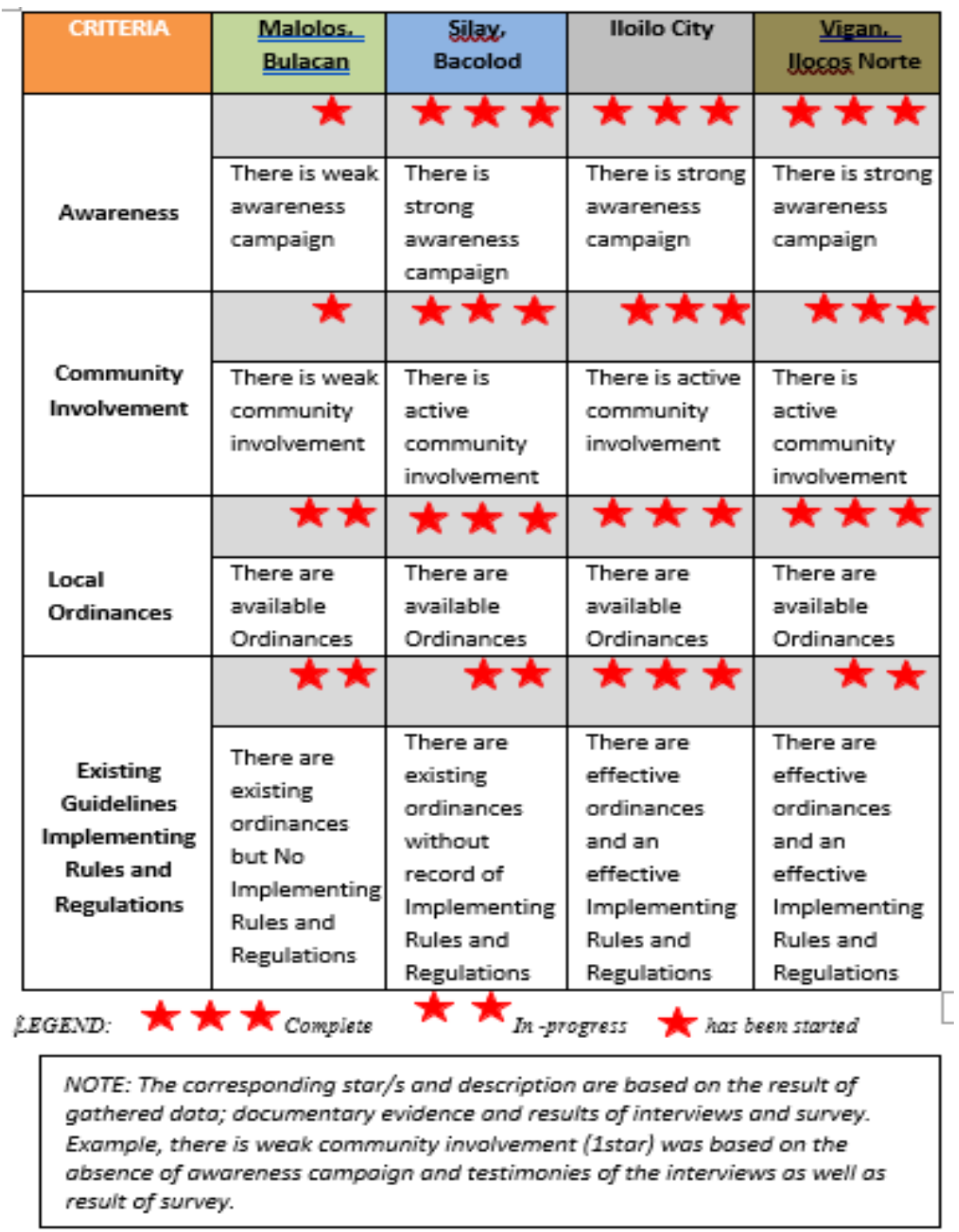


Table 2: City Ordinance in Heritage Conservation

\begin{tabular}{|c|c|}
\hline City & Ordinances in Heritage Conservation \\
\hline $\begin{array}{l}\text { Malolos } \\
\text { City. } \\
\text { Bulacan }\end{array}$ & $\begin{array}{l}\text { 1. The heritage administrative authority ordinance } \\
2 . \quad \text { Anti-demolition of heritage property ordinance } \\
\text { 3. Heritage preservation Ordinance of the City of Maloles. } \\
\text { City Ordinance No.14-201 }\end{array}$ \\
\hline $\begin{array}{l}\text { Silax City, } \\
\text { Negros } \\
\text { Occidental }\end{array}$ & $\begin{array}{l}\text { 1. Landmark heritage ordinance, giving 100-percent tax } \\
\text { exemption for owners of heritage structures who properly } \\
\text { maintain and adaptively reuse their properties. }\end{array}$ \\
\hline Hlollo Cty & 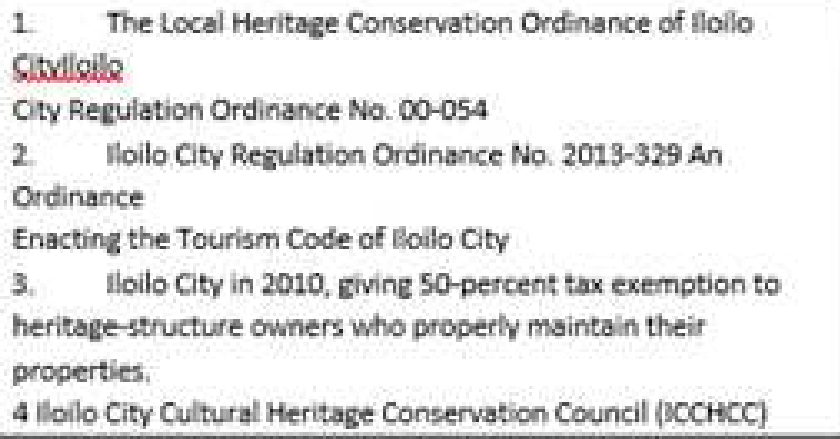 \\
\hline $\begin{array}{c}\text { Vigan, } \\
\text { leces. Norte }\end{array}$ & $\begin{array}{l}\text { 1. Cty Ordinance No. 12,5.1997 delineating the boundaries of } \\
\text { the historic core and buffer zones of the World Heritage Site; } 2 \text {. } \\
\text { Crty Ordinance No. 14, S.1997 defining the allowable uses in } \\
\text { the core and buffer zones; } \\
\text { 3. City Ordinance No, } 7,5.2006 \text { providing the Vigan Conservation } \\
\text { Guidelines which provides guidelines for appropriate restoration } \\
\text { works on historic structures, construction of new structures and } \\
\text { development of open spaces within the protected zones. }\end{array}$ \\
\hline
\end{tabular}

Vigan was able to organize and empower the local community to become primary stakeholders and keepers of their tangible and intangible cultural heritage, the sustainability of Vigan's conservation management lies in it, which stems from being the primary trading post in Northern Philippines during the Spanish era. (UNESCO, Heritage City of Vigan). Vigan has Conservation Guidelines for appropriate restoration works on historic structures, construction of new structures and development of open spaces within the protected zones.

Iloilo was able to establish Iloilo City Cultural Heritage Conservation Council (ICCHCC) and its guidelines and Implementing Rules and Regulations. ICCHCC led the on-going project the Conservation Planning and Development for Iloilo City Heritage Structures and Sites and giving 50-percent tax exemption to heritagestructure owners who properly maintain their properties. (Cabañero, 2017)

The mayor of Silay in 2015, announced a landmark ordinance that more or less guaranteed the continuance of heritage efforts, giving the owners of heritage structures, "who properly maintain and adaptively reuse their properties," 100-percent tax exemption. Today, these heritage houses, numbering about 30 , have become the 
engines fueling the local economy of Silay, much like Vigan. Some have become museums, others have become charming boutique hotels as well as bed-and-breakfasts, all of them embracing the past and reusing it for contemporary purposes. (Casocot, 2019)

Malolos having three ordinances for heritage conservation and may create similar ordinances for IRR, Conservation Guidelines and tax exemption to safeguard its own heritage district.

\section{F. SWOT ANALYSIS of Kamestizuhan Heritage District}

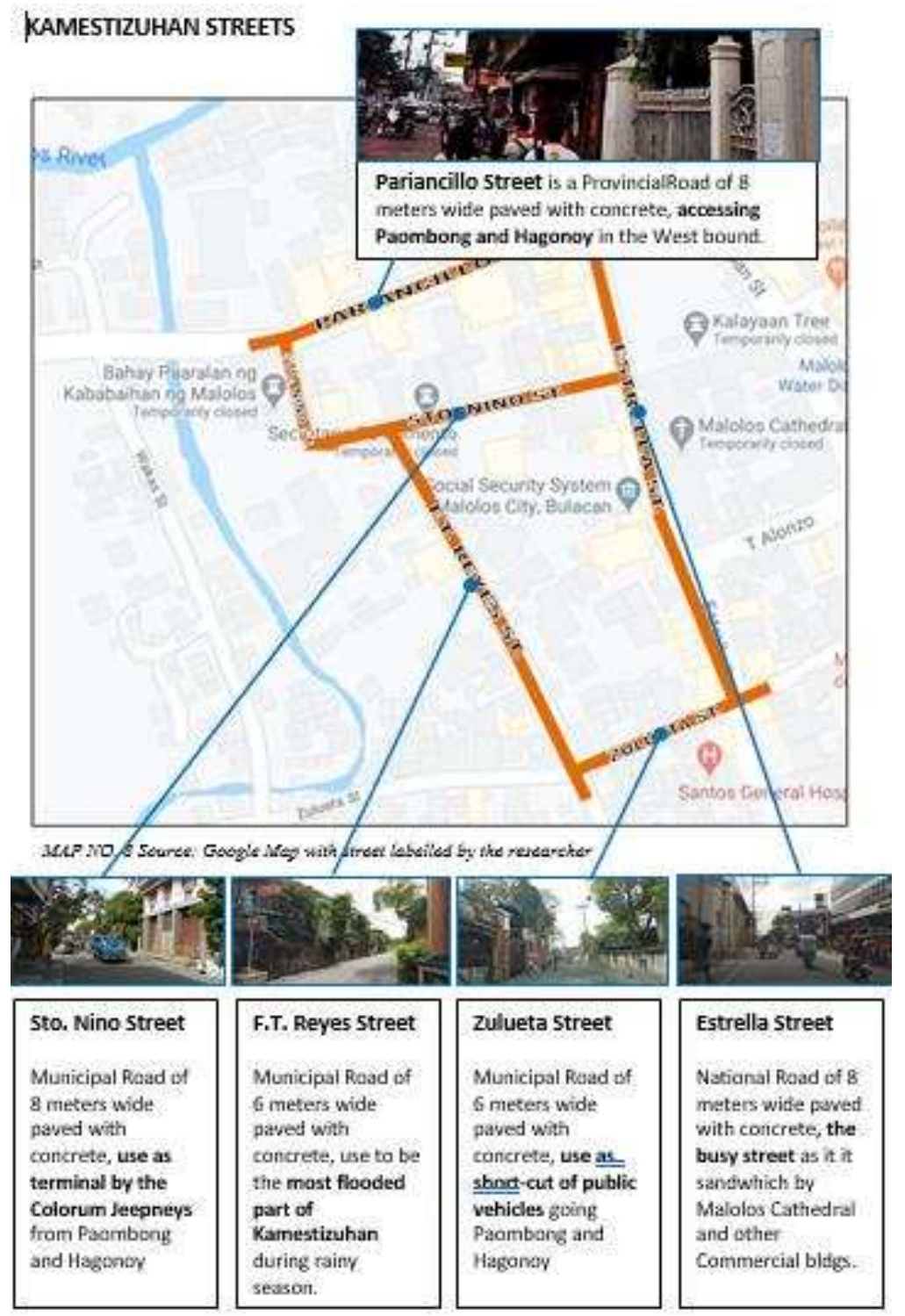

Kamestizuhan is situated at the very heart of Malolos Town properly. Commercialization is fast growing and flourishing in the area. Heritage private properties are potential target of investors and businessmen for their target businesses. The F.T. Reyes Street (Municipal Road) of 6 meters wide paved with concrete and asphalt overlay, use to be flooded heavily during rainy season due to poor sewerage system and clogged canal affecting Sto Niño and Zulueta Streets causing the Don Luis Santos House, Alberta Uitangcoy House and the Hermogenes House to be flooded. Insufficient light posts to illuminate the streets of Sto Niño, Zuleta Street at night. The street of Sto. Niño is being utilized as sidewalk parking by the colorum jeepneys and private vehicles who are customers of the adjoining commercial establishments in the area.

There are remaining local flora and fauna in the area particularly in the compound of the ancestral houses. Local trees are limitedly thriving. Available open spaces are privately owned with limitations for vegetation. 
Map of Pariancillo, or the Kamestizuhan District, ca. 1888

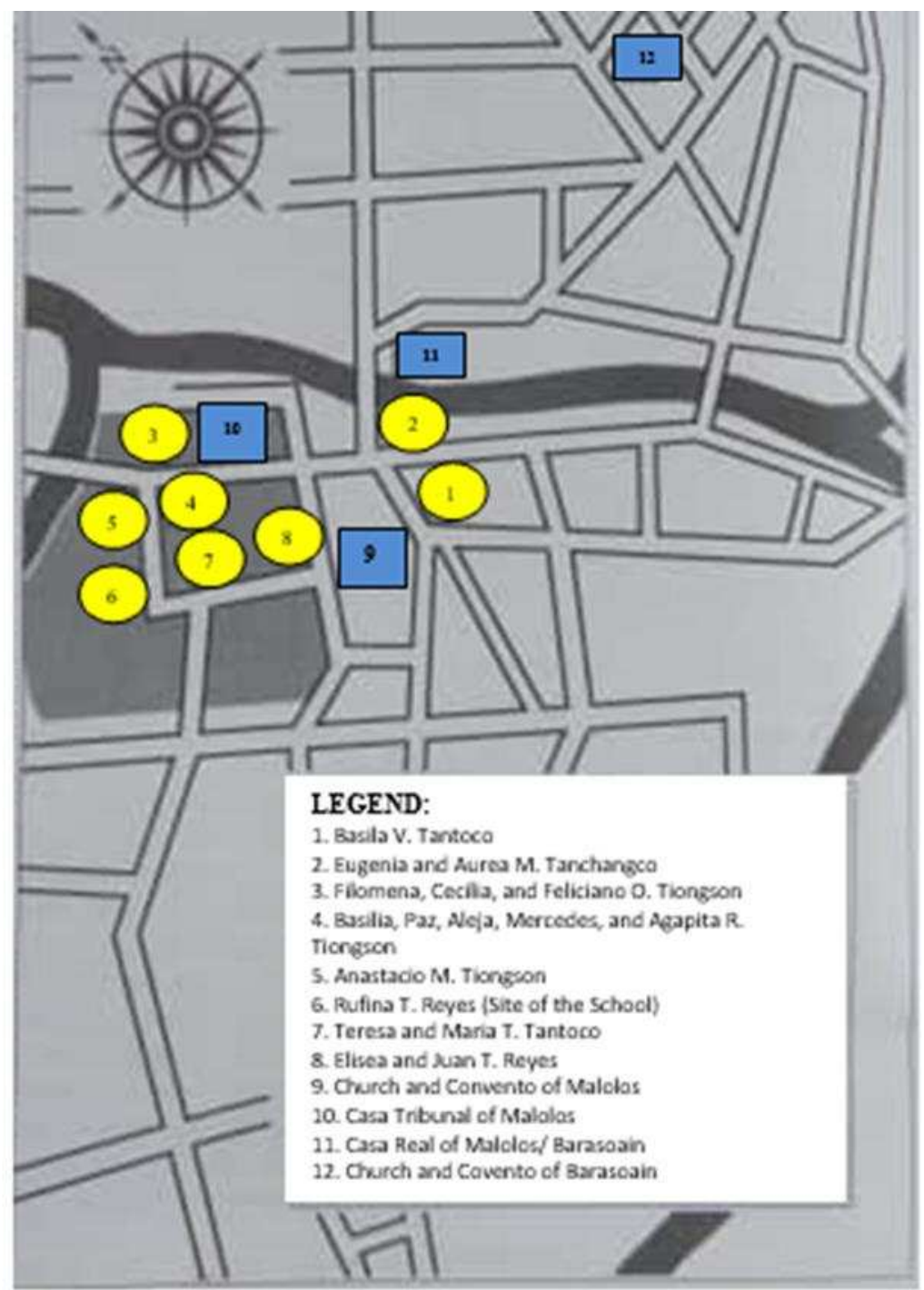

MAP No 1. Source: The Women of Malolos, page 147

Map of Pariancillo, or the Kamestizuhan District, ca. 1888, showing the location of the houses of the twentyone Women of Malolos, except those of Leoncia and Olympia Reyes and Alberta Uitangcoy which could not be identified by their heirs. (Tiongson, 2004). 


\section{G. MAPS:}

\section{LAND USE MAP OF MALOLOS KAMESTIZUHAN (year 1998-2018)}

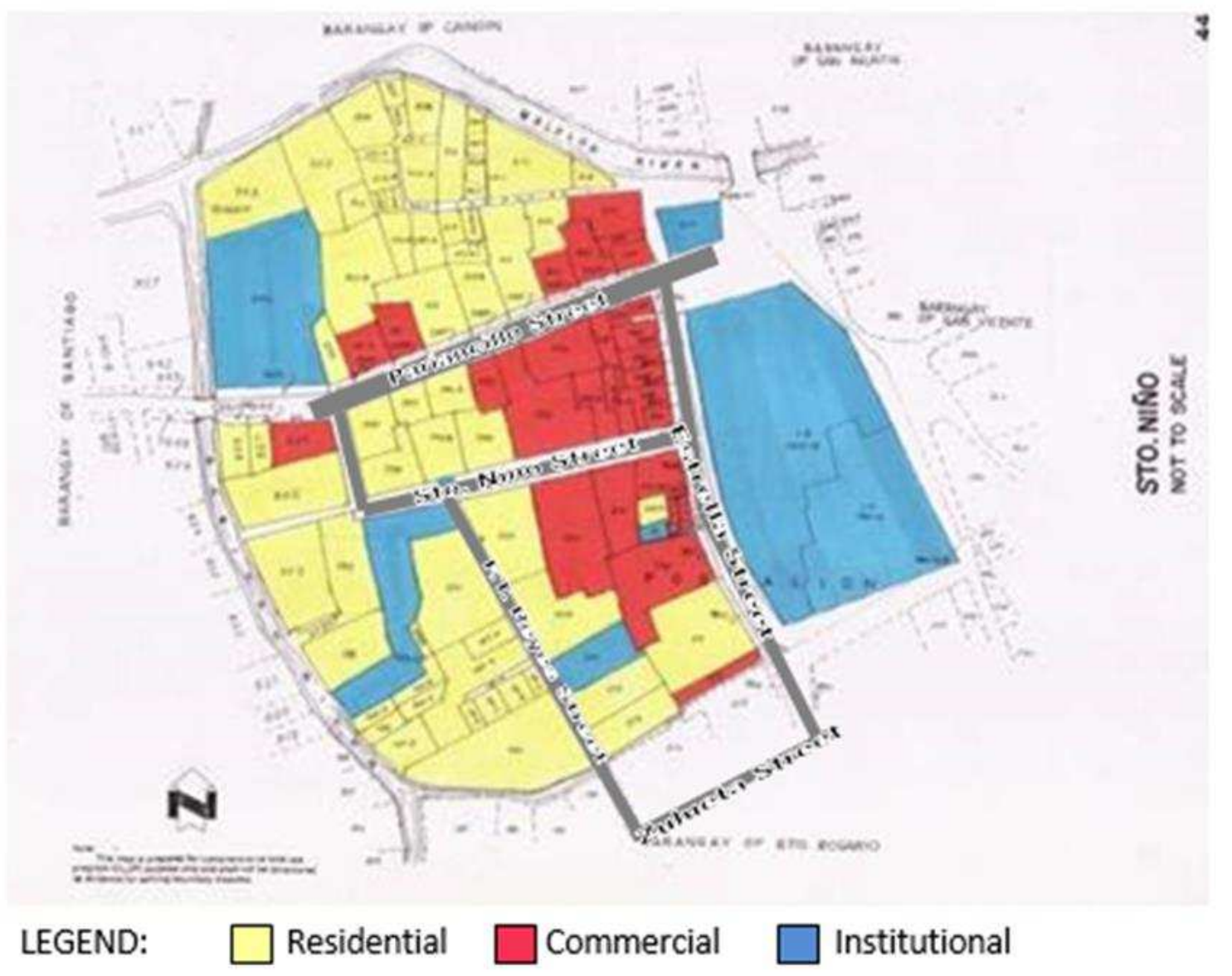

MAP NO 2. Source: Municipal Planning and Development Office, Malolos

The above Land Use Map of Kamestizuhan Heritage District shows that almost one half of fifty percent (50\%) of the heritage district is commercial in use and the remaining half of the area is residential in use. Partly, there are reflected Institutional in the land use map. 


\section{HERITAGE STRUCTURES AND ITS USES (as of 1998)}

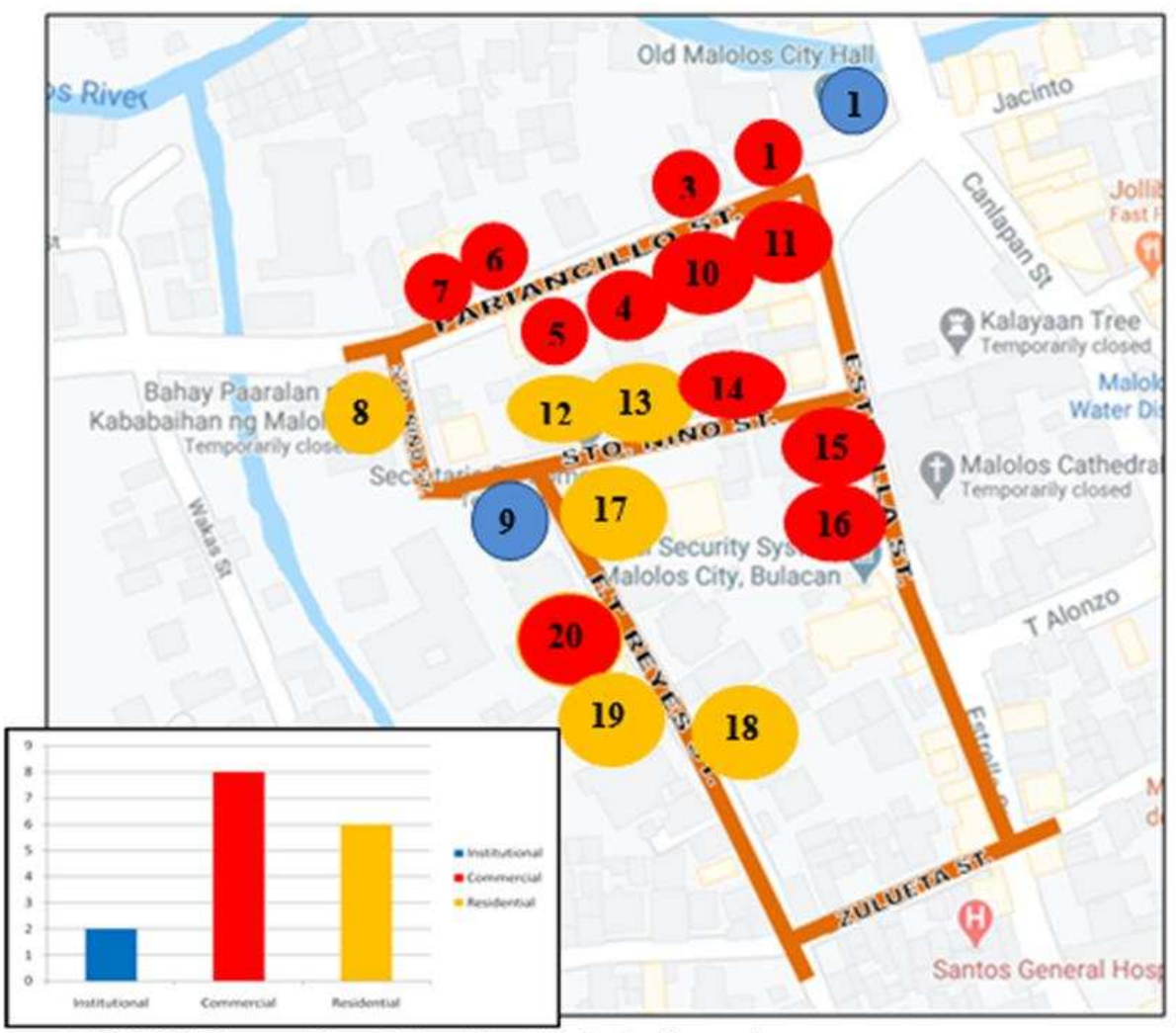

MAP NO 3. Source: Google Map. Graphics bv the Researcher

LEGEND: Institutional

Commercial

Residential

Table 4: Existing use of structures

\begin{tabular}{|l|l|l|l|}
\hline No. & Name & No. & Name \\
\hline 1. & Malolos City Hall & 11. & Tiongson House \\
\hline 2. & Aurelio Crisostomo House & 12. & Jaconto Lomotan House \\
\hline 3. & Ponciano Tiongson House & 13. & Vicenta Tantoco House \\
\hline 4. & Eden Cinema & 14. & Tantoco House \\
\hline 5. & Adriano-Vasquez House/ MERALCO & 15. & Estrella \\
\hline 6. & Vicente Tiongson House & 16. & Lino Reyes House \\
\hline 7. & Casa Tribunal & 17. & Bautista House \\
\hline 8. & Rufina T. Reyes (Site of the School) & 18. & Luis Santos House \\
\hline 9. & Sto. Nino Chapel & 19. & Alberta Uitangcoy House \\
\hline 10. & Erasto Cervantes House & 20. & Hermogenes House \\
\hline
\end{tabular}




\section{DEMOLISHED HERITAGE STRUCTURES (as of 2020)}

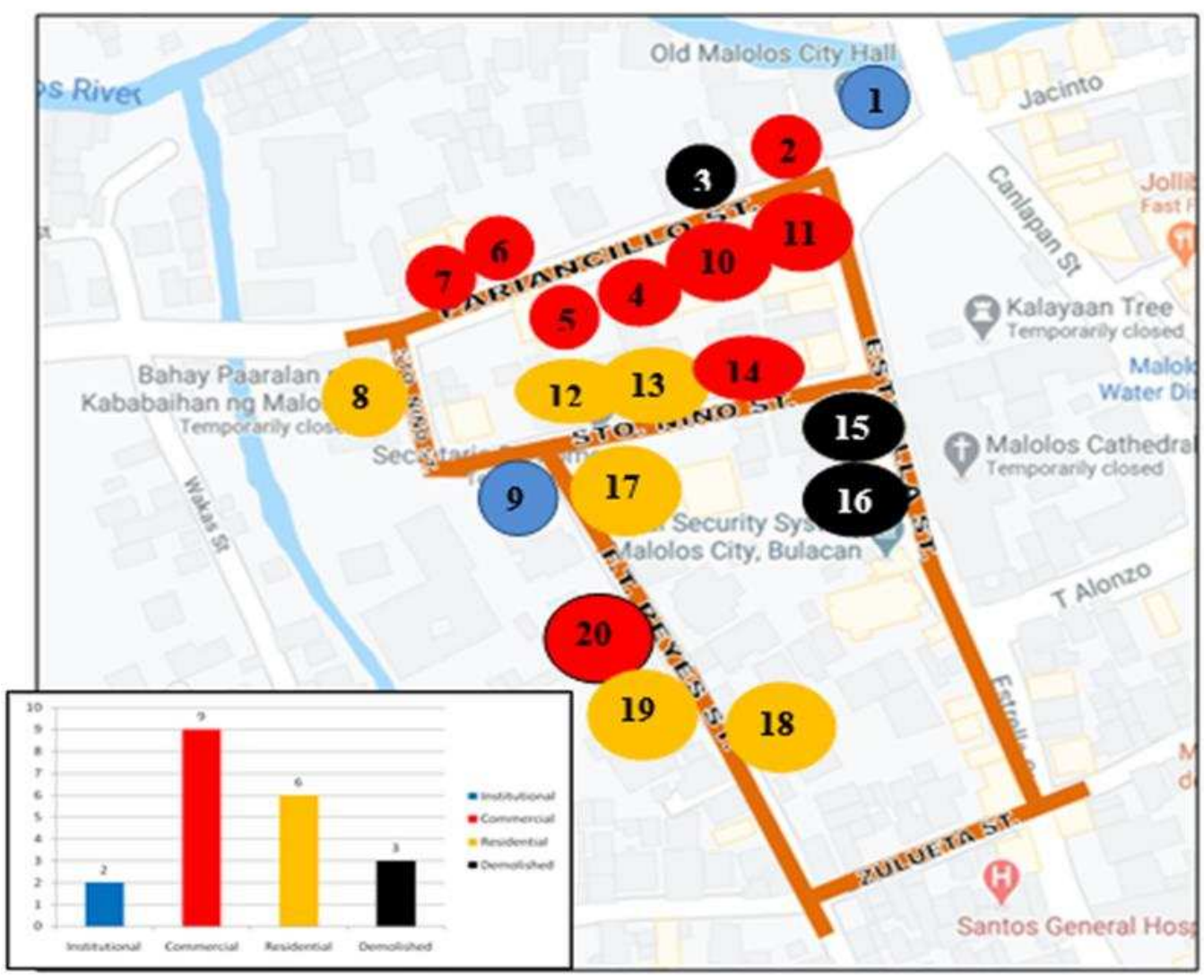

MAP NO 4. Source: Google Map, Graphics by the Resecrcher

Table 5: The identified demolished structures

\begin{tabular}{|l|l|l|l|}
\hline No. & Name & No. & Name \\
\hline 1. & Malolos City Hall & 11. & Tiongson House \\
\hline 2. & Aurelio Crisostomo House & 12. & Jaconto Lomotan House \\
\hline 3. & Ponciano Tiongson House & 13. & Vicenta Tantoco House \\
\hline 4. & Eden Cinema & 14. & Tantoco House \\
\hline 5. & Adriano-Vasquez House/ MERALCO & 15. & Estrella \\
\hline 6. & Vicente Tiongson House & 16. & Lino Reyes House \\
\hline 7. & Casa Tribunal & 17. & Bautista House \\
\hline 8. & Instituto de Mujeres & 18. & Luis Santos House \\
\hline 9. & Sto. Nino Chapel & 19. & Alberta Uitangcoy House \\
\hline 10. & Erasto Cervantes House & 20. & Hermogenes House \\
\hline
\end{tabular}


At present, there are installed municipal markers in eleven heritage structures in Kamestizuhan Heriatge District with and only two heritage structures bearing the Markers National Historical Commission of the Philippines.

There are twelve heritage structures that are commercial in land use; seven are residential in land use, and two are Institutional.

Four of the Heriatge Structres were already demolished, namely; Ponciano Tionson House (use as commercialparking lot) , Estrella Cinema (three storey commercial building of McDonalds), Lino Reyes House (sold to Las Casas and now use as commercialparking lot), and Hermogenes House (sold to be used as Bread and Breakfast).

Six of the Heritage Structures are historically significant

Kamestizuhan heritage district comprises multiple architectural styles: Six (6) Art Deco, three (3) Art Noveau, seven (7) Bahay Mestiza four (4) Bahay na Bato.

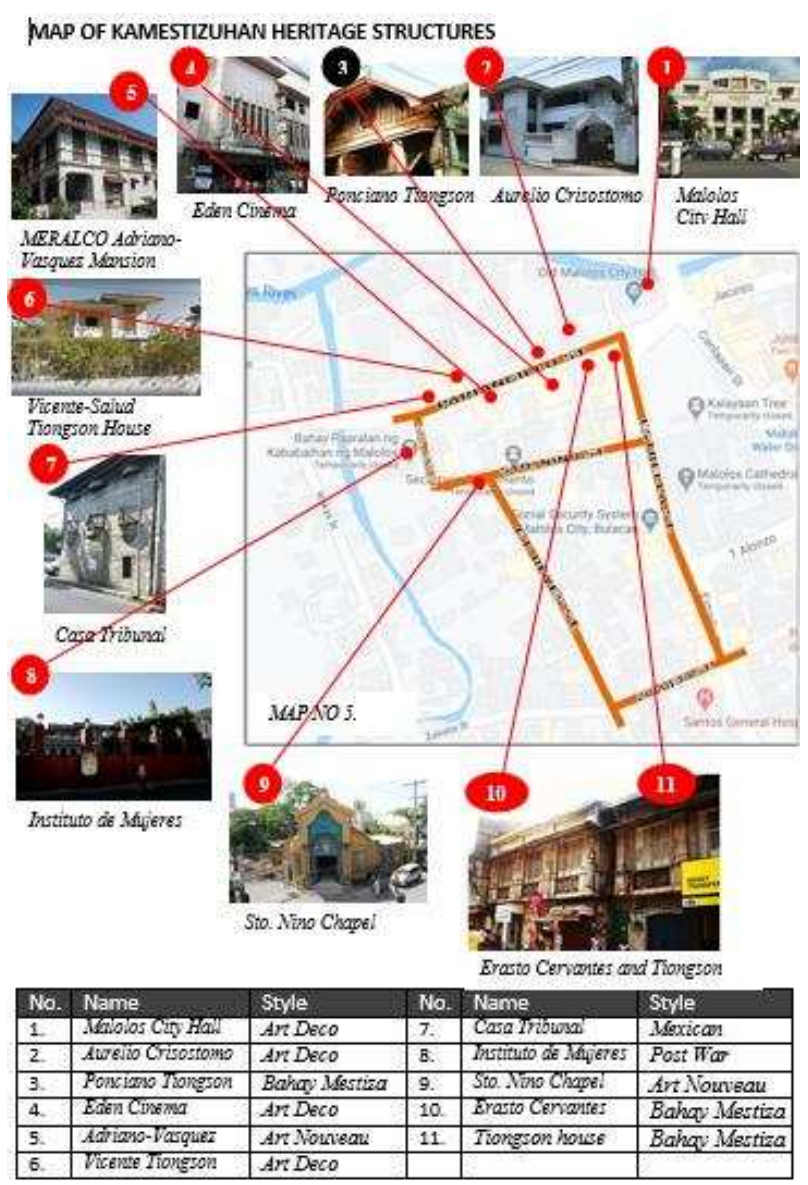

Table 6: Inventory of architectural style

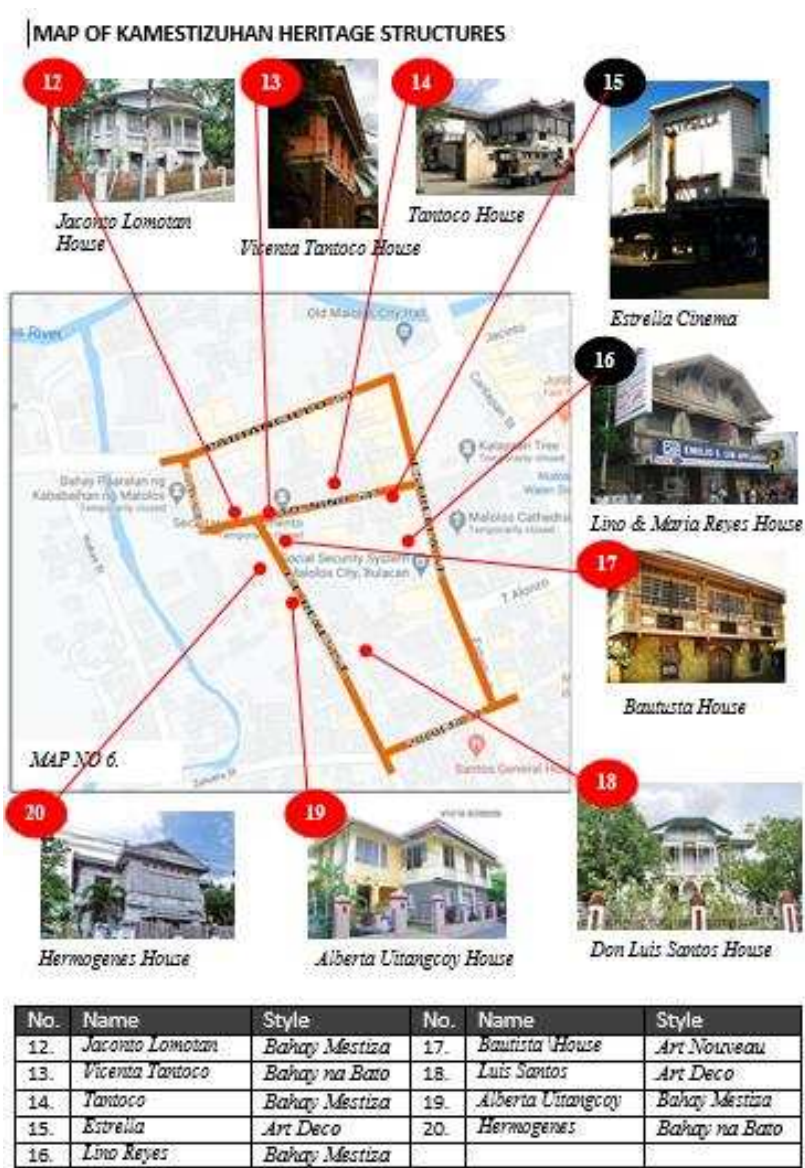

Table 7: Inventory of architectural style 
Houses in Kamestizuhan that served as offices of the First Philippine Republic and Schools Of 21 Women of Malolos

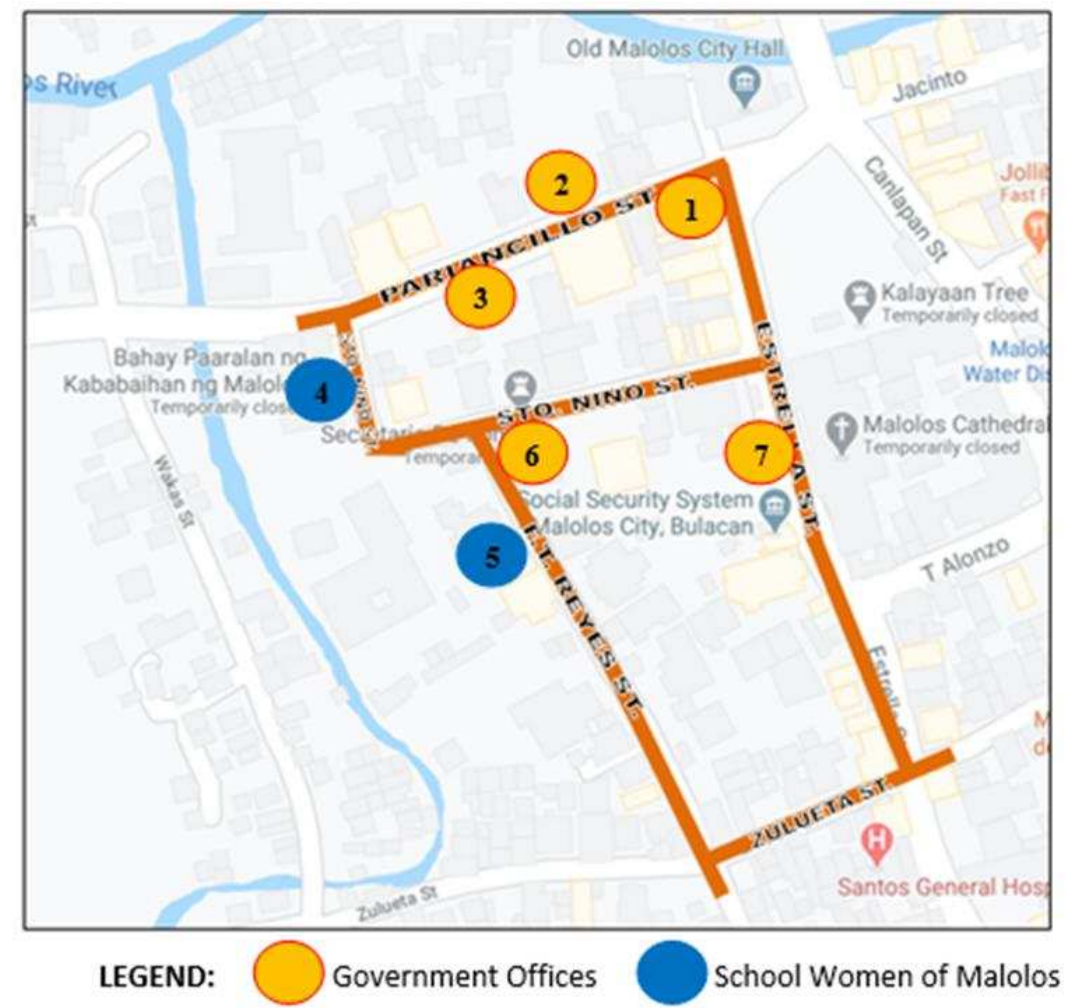

Map No. 5 Source: google map, graphic by the researcher

Table 8: Heritage Structures used as government Offices during the 1st Phil. Republic

\begin{tabular}{|l|l|l|l|}
\hline No. & \multicolumn{1}{|c|}{ Name of House } & \multicolumn{1}{c|}{ Served as Office of: } & \multicolumn{1}{c|}{ Used by: } \\
\hline 1. & Ponciano TiongsonHouse & Commisaira de Guerra & Apolinario Mabini \\
\hline 2. & Erasto Cervantes House & Secretaria de Interior & Antonio Luna \\
\hline 3. & Adriano-Vasquez House & $\begin{array}{l}\text { Gobierno Militar de } \\
\text { Plaza }\end{array}$ & Isidoro Torres \\
\hline 4. & Rufina T. Reyes House & Instituto de Mujeres & 21 Women of Malolos \\
\hline 5. & Alberta Uitangcoy House & $\begin{array}{l}\text { Night School of the } \\
\text { Women of Malolos }\end{array}$ & $\begin{array}{l}\text { Group leader-Alberta } \\
\text { Uitangcoy }\end{array}$ \\
\hline 6. & Don Jose Bautista House & Sercetaria de Fomento & Don Jose Bautista \\
\hline 7. & Lino Reye House & Secretaria de Exteior & Apolinario Mabini \\
\hline
\end{tabular}


The graph below is the summary of the assessment of the heritage structures based on its significance (economic, social, architectural and historical). Group of architects in Bulacan State University were invited to assess each of the structures.

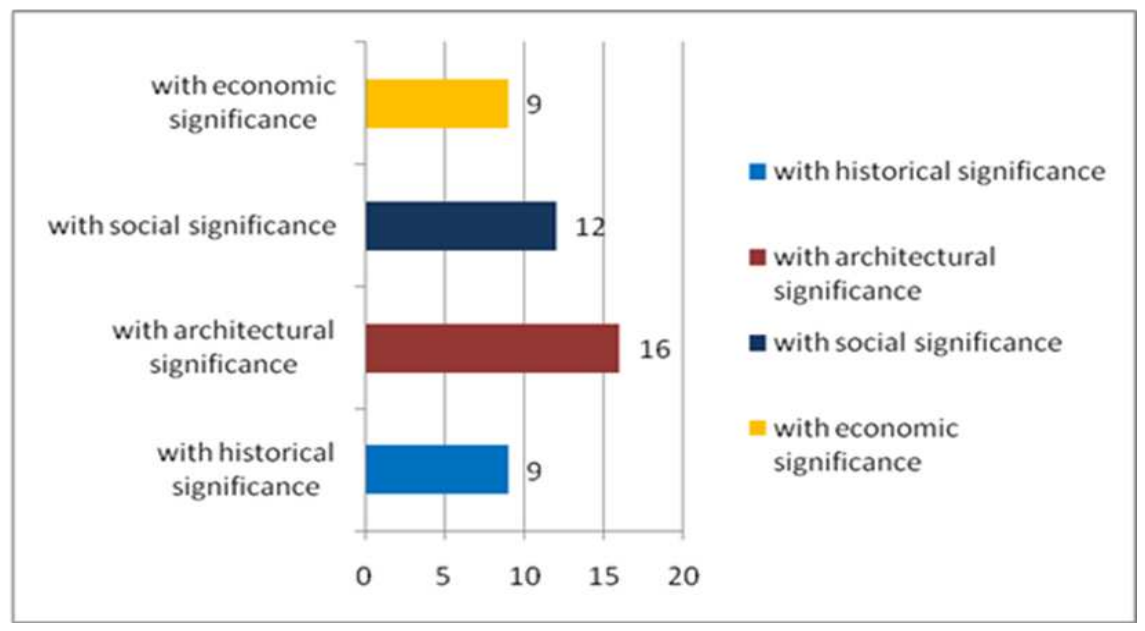

Graph showing the summary of results of assessed significance

Out of the twenty Heritage Structures in Kamestizuhan District, nine structures have strong historical significance (4.5 squares) and sixteen has Aesthetic or architectural significance (4.0 squares). Twelve structures has social significance (3.0 squares) and nine structures economic significance (3.o square).

\section{INVENTORY OF MARKERS}

4 Table No 5: Inventory of Heritage Structures with Markers

\begin{tabular}{|c|c|c|c|}
\hline No. & NAME OF STRUCTURES & $\begin{array}{c}\text { With } \\
\text { Municipal } \\
\text { Marker }\end{array}$ & $\begin{array}{c}\text { With } \\
\text { NHCP } \\
\text { Marker }\end{array}$ \\
\hline 1. & Malolos City Hall & & \\
\hline 2. & Aurelio Crisostomo House & & \\
\hline 3. & Ponciano TiongsonHouse & & \\
\hline 4. & Eden Cinema & & \\
\hline 5. & Adriano-VasquezHouse & & 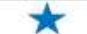 \\
\hline 6. & Vicente Tiongson House & & \\
\hline 7. & Casa Tribunal & & \\
\hline 8. & Rufina T. Reyes (Site of the School) & $r$ & \\
\hline 9. & Sto. Nino Chapel & & \\
\hline 10. & Erasto CervantesHouse & s & \\
\hline 11. & Tiongson House & & \\
\hline 12. & Jaconto Lomotan House & 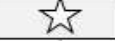 & \\
\hline 13. & Vicenta TantocoHouse & 茨 & \\
\hline 14. & Teresa and Maria Tantoco House & 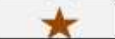 & \\
\hline 15. & EstrellaHouse & 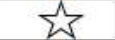 & \\
\hline 16. & Lino RexesHouse & & \\
\hline 17. & Jose Bautista House & 文 & $\sum$ \\
\hline 18. & Luis SantosHouse & 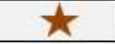 & $\sum$ \\
\hline 19. & Alberta Uitangcoy-Santos & J & W \\
\hline 20. & HermogenesHouse & 药 & 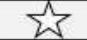 \\
\hline
\end{tabular}

There are eleven (11) heritage structures in Kamestizuhan Heritage District with installed municipal markers and only two (2) heritage structures have the National Historical Commission of the Philippines Markers 
Table 6f Survey: Malolos City/ Local Government Action

\begin{tabular}{|c|c|c|c|c|c|c|}
\hline $\begin{array}{l}\text { II. Malolos City/ } \\
\text { Local Government } \\
\text { Action }\end{array}$ & $\begin{array}{c}\text { CGO } \\
\text { Weighted } \\
\text { Mean }\end{array}$ & $\begin{array}{l}\text { Adv./ Aca } \\
\text { Weighted } \\
\text { Mean }\end{array}$ & \begin{tabular}{c|} 
Students \\
Weighted \\
Mean
\end{tabular} & $\begin{array}{c}\text { Local } \\
\text { Weighted } \\
\text { Mean }\end{array}$ & $\begin{array}{l}\text { Grand } \\
\text { Mean }\end{array}$ & Interpretation \\
\hline $\begin{array}{l}\text { 1.) The Heritage } \\
\text { District of Malolos is } \\
\text { included in the } \\
\text { Government } \\
\text { Development Plan }\end{array}$ & 4.0 & 3.5 & 3.7 & 3.6 & 3.7 & $\begin{array}{l}\text { Strongly } \\
\text { Agree }\end{array}$ \\
\hline $\begin{array}{l}\text { 2.) There is an existing } \\
\text { conservation } \\
\text { management plan for } \\
\text { the Heritage District of } \\
\text { Malolos }\end{array}$ & 3.5 & 1.2 & 3.5 & 2.6 & 2.7 & Disagree \\
\hline $\begin{array}{l}\text { 3.) The current } \\
\text { condition of } \\
\text { Kamestisubar Heritage } \\
\text { zone manifest that } \\
\text { there is an existing and } \\
\text { effective conservation } \\
\text { management plan }\end{array}$ & 3.7 & 2.0 & 3.2 & 3.0 & 2.97 & Disagree \\
\hline $\begin{array}{l}\text { 4.) There are city } \\
\text { ordinances that } \\
\text { protect the heritage } \\
\text { district of Malolos }\end{array}$ & 3.8 & 3.1 & 3.7 & 3.8 & 3.6 & $\begin{array}{l}\text { Strongly } \\
\text { Agree }\end{array}$ \\
\hline $\begin{array}{l}\text { 5.) There are existing } \\
\text { Implementing Rules } \\
\text { and Regulations for } \\
\text { the Conservation and } \\
\text { protection of Malolos } \\
\text { Heritage District }\end{array}$ & 2.5 & 1.0 & 3.4 & 1.8 & 2.17 & Disagree \\
\hline $\begin{array}{l}\text { 6.) The Local } \\
\text { Government is } \\
\text { allotting sufficient fund } \\
\text { for the conservation of } \\
\text { Malolos Heritage } \\
\text { District }\end{array}$ & 3.8 & 3.7 & 3.7 & 2.5 & 3.42 & Agree \\
\hline
\end{tabular}

Table Z: Survey: Stakeholders' Participation

\begin{tabular}{|l|c|c|c|c|c|c|}
\hline $\begin{array}{l}\text { Stakeholders' } \\
\text { Participation }\end{array}$ & $\begin{array}{c}\text { CGO } \\
\text { Weighted } \\
\text { Mean }\end{array}$ & $\begin{array}{c}\text { Adv. } \\
\text { Weighted } \\
\text { Mean }\end{array}$ & $\begin{array}{c}\text { Students } \\
\text { Weighted } \\
\text { Mean }\end{array}$ & $\begin{array}{c}\text { Local } \\
\text { Weighted } \\
\text { Mean }\end{array}$ & $\begin{array}{c}\text { Grand } \\
\text { Mean }\end{array}$ & Interpretation \\
\hline $\begin{array}{l}\text { 1.) There are available } \\
\text { research proposals for the } \\
\text { conservation } \\
\text { (oreservation, restorotion, } \\
\text { etc.) of Malolos Heritage } \\
\text { District }\end{array}$ & 3.5 & 4.0 & 3.7 & 3.7 & 3.73 & $\begin{array}{c}\text { Strongly } \\
\text { Agree }\end{array}$ \\
\hline $\begin{array}{l}\text { 2.) There is/are scholastic } \\
\text { study/ies for the } \\
\text { protection of } \\
\text { Kamestisuhan Heritage } \\
\text { District }\end{array}$ & 3.4 & 3.9 & 3.8 & 3.7 & 3.70 & $\begin{array}{c}\text { Strongly } \\
\text { Agree }\end{array}$ \\
\hline $\begin{array}{l}\text { 3.) The local government } \\
\text { supports the submitted } \\
\text { research/ scholarly } \\
\text { proposals for the } \\
\text { conservation of Malolos } \\
\text { Heritage District }\end{array}$ & 3.8 & 2.5 & 3.7 & 3.6 & 3.40 & Agree \\
\hline $\begin{array}{l}\text { 4.) There are collaborative } \\
\text { effort of the academe, } \\
\text { government and industry } \\
\text { in safeguarding the } \\
\text { Heritage District of } \\
\text { Malolos }\end{array}$ & 3.0 & 2.1 & 3.3 & 3.6 & 3.00 & Agree \\
\hline $\begin{array}{l}\text { 5.) The Kamestisuhan } \\
\text { Heritage District ancestral } \\
\text { houses are intact, well } \\
\text { preserved and well } \\
\text { maintained by the owners }\end{array}$ & 3.7 & 3.0 & 3.6 & 3.5 & 3.45 & Agree \\
\hline
\end{tabular}

Result showed that $89 \%$ of the respondents strongly agreed in the factor that heritage district of Malolos is included in the Government Development Plan (Grand Mean 3.7/Strongly Agree) but Disagree that there are existing Implementing Rules and Regulations for the Conservation and protection of Malolos Heritage District (Grand Mean 2.17/ Disagree) and $85 \%$ of the respondents disagreed in the factor that there an existing conservation management plan for the Heritage District of Malolos (Grand Mean 2.7/ Disagree).
Most of the respondents strongly agreed in the factor that there are available research proposals for the conservation (Grand Mean 3.73/Strongly Agree). 93\% of the Academe and heritage advocate respondents disagreed (Weighted Mean 2.10) that there are collaborative effort of the academe, government and industry in safeguarding the Heritage District of Malolos. 


\title{
Conclusion
}

The result of comparative analysis shows that since 2001 that Malolos became a heritage zone, it has produced three Ordinances, with No IRR unlike Vigan and Iloilo. The absence of IRR was affirmed by the documentary evidence, testimonials of the interviewees, and supported by the result of the conducted survey. The politician particularly the City Mayor plays the key role in the initiative to strengthen the available ordinances in safeguarding Kamestizuhan.

There are only eleven heritage structures in Kamestizuhan Heritage District with installed municipal markers and only two heritage structures bearing the Markers National Historical Commission of the Philippines. From the long period of time that Malolos Town became heritage district, only two NHCP markers were installed, this is because the local government officials in the past, assume that heritage conservation is not profitable, resulting to conversion of the $50 \%$ of the land into commercial use, making the heritage structures vulnerable to destruction.

The strategy of Silay giving 100-percent tax exemption and same approach of Iloilo giving $50 \%$ for owners of heritage structures who properly maintain and adaptively reuse their properties turned out to be effective and helpful in heritage conservation.

Triple Helix approach was proven to be effective in safeguarding cultural heritage. Community alone cannot handle the protection of the tangible heritage properties without the direct assistance of the local government in creating ordinances for the heritage protection, likewise the academe plays an important role as they provide scholastic research for heritage conservation.

The local community must be the first one to appreciate and be aware of the rich cultural heritage of in their community. Education is the best instrument to disseminate awareness.

\section{Recommendations}

1.) Creation of Guidelines/ Policy for Conservation of the Historical District

1. The heritage administrative authority ordinance

2. Anti-demolition of heritage property ordinance

3. Heritage preservation Ordinance of the City of Malolos City Ordinance No.14-2013

must be supported by Implementing Rules and Regulations to solidify, strengthen and enforcement of the city ordinances in the conservation and preservation of the Malolos Heritage District.

2. Installations of Historical Markers- Historical markers by the National Historical Commission of the Philippines

\author{
Malolos Heritage Council \\ Grupo Kalinangan Incorporated \\ Sineliksik Bulacan
}

Local Government of Malolos should collaborate, prioritize, assess and submit request for NHCP for the installation of NCHP Markers to the remaining cultural heritage structures in Kamestizuhan.

\section{CONSERVATION MANAGEMENT PLAN}

The intent of this Design Guideline is to establish the architectural, cultural, social character and quality of the natural and built environment at the Kamestizuhan Heritage District of Malolos City. It outlines the recommendatory physical, architectural, landscape, and urban design characteristics intended for the district with the guidance of the national codes and other guidelines made for the heritage sites. 
The criteria and patterns described in this guideline can ensure a degree of harmony among all design elements that comprise the Kamestizuhan Heritage District of Malolos City. Thus, it can guide the construction of buildings within the area.

\section{General Conservation Policy (NHCP)}

No part of the Heritage Houses shall be altered, modified, removed or replaced that will cause to the loss of its significance in terms of architectural features in conformity to its era. Any action of conservation must be in accordance with the existing guidelines governing the protection of the cultural heritage house.

\section{KAMESTIZUHAN HERITAGE DISTRICT CONSERVATION CONCEPT}

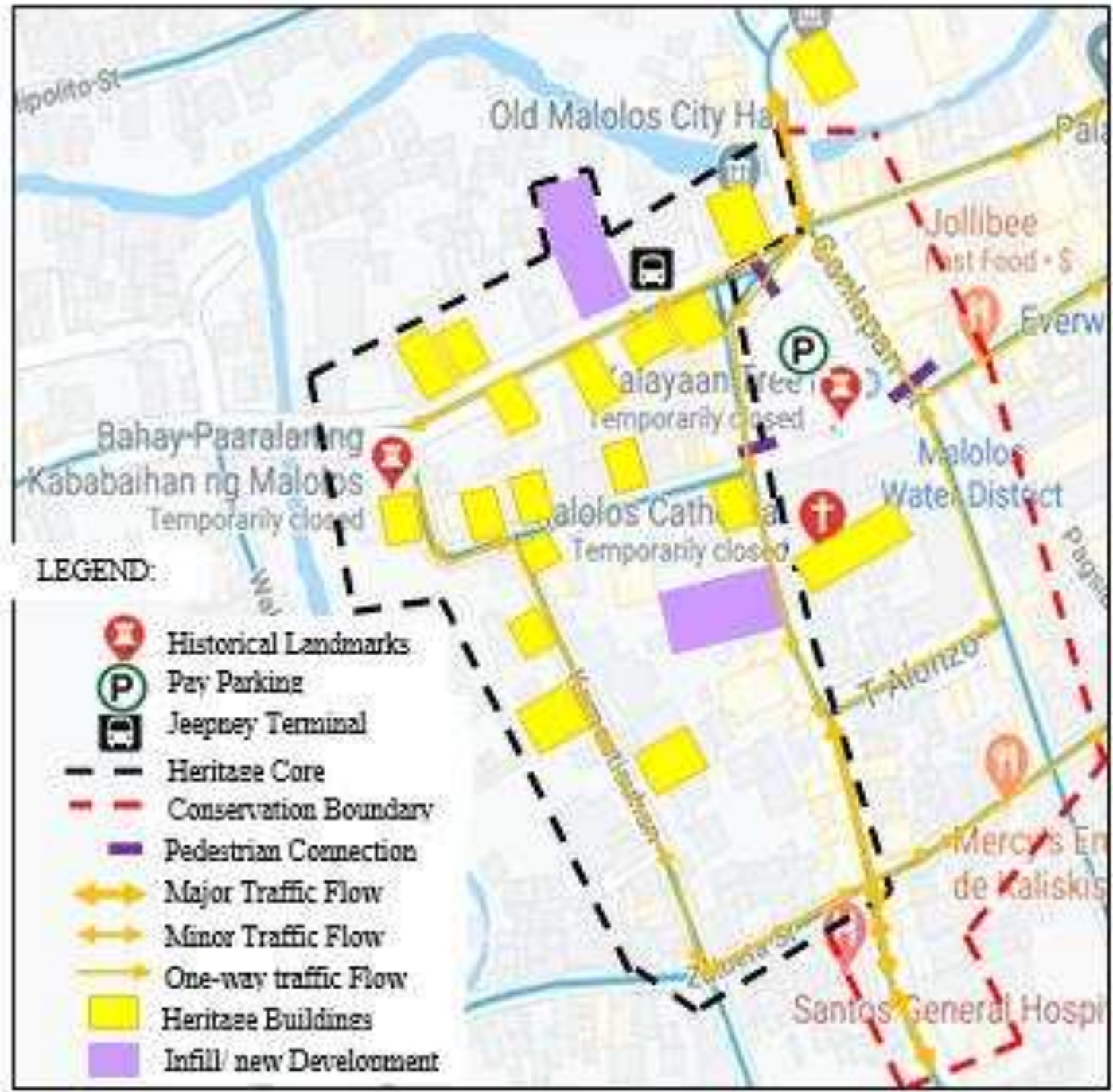

Map source: Googie Mops, Lepends andraminics by the researcher 


\section{Acknowledgements}

This research endeavor will not be possible without the help of the local government of Malolos, Malolos Tourism and Engineering Office, Bulacan State University and University of Santo Tomas.

\section{References}

Alambag, Windy T., et.al., Urban Conservation at the Central Business district of Boac Marinduque through Adaptive Reuse., LG 996 A43pu., 2018

Alarcon, Norma I., Philippine Architecture during the Pre-Spanish and Spanish period, UST publishing house, Manila, Phil. Rev.Ed. 1998

Amante, Liane Stephanie V., et.al., Redevelopment of Binondo: As a Chines Parian, A livable Environment for the Chinese-Filipino Community., TU 15893 A43rb, 2017

Ateneo de Manila University, The World of 1896, Philippine Telecommunication, 1998

Dizon, Sherwin T., Polintan, Kristine C Preserving Historical and Cultural Heritage: A Prototype Development Envisioned for The City of Manila, Th067, Bulacan State University

Dimagiba, Eliza V. Pacho, Ferdinand DC., Redevelopment of Historical and Commercial District (Calle Escolta De Manila), Th075, Bulacan State University, 2007

Javellana, Rene, et.al., Filipino Style, Archipelago Press, Singapore, 2005

Manahan, G.V., Philippine Architecture in the 20th Century, UP College of Architecture, Q.C., 1986

Perdon, Renato, (2015). Historic Preservation in the Philippines, Munting Nayon, Protecting the Past for the Future: Proceedings of the UNESCO Regional Conferences on Historic Places, Sydney, Australia: 22-28 May 1983

Malolos Development Plan, Malolos Planning and Development Office, City of Malolos, 2018

Martinez, Francis Gabriel T., Santiago, Gilbert Q., Bahay Na Bato Inspired Cultural Complex: A Study of Common Architectural Feature to Preserve Bulacan Heritage Architecture, Th061, Bulacan State University, 2006

Santos, Alexandra A.,Santos, Christhoper, Poblacion: harmonizing the Old and the New Town Centers of Bocaue., NA 4170 S26ph, 2015

Santiago, M., Wilson L. Perez, Benedict, Restoring The Images of The Past: A Paradores System Approach In Conserving Heritage Structure Th093, Bulacan State University, 2008

Tettoni, Luca and Reyes, Elizabeth V., Philippine Style, Design and Architecture, Anville Publishing Inc., Mandaluyong City, Philippines, 2013

The Spanish Colonial Tradition 1565-1898, National Library if the Philippines, 2015

Tiongson, Nicanor, The Women of Malolos, Ateneo de Manila University, Ateneo University Press, 2004

\section{JOURNALS}

Ahmad, A Ghafar, Cultural Heritage of Southeast Asia : Preservation for World Recognition, Journal of Malaysian Town Plan: Vol. 03, Issue 01, Jan. 2006. pg. 52-62

Arreola, Daneil, et.al., Ciudad Chihuahua: Its Changing Morphology and Landscape, Aeizona State University, USA 1994

Artese, Maria Teresa, et. al., (2017). Evaluating perceptual visual attributes in social and cultural heritage web sites, Journal of Cultural Heritage: Volume 26, July- August 2017, Pages 91-100, https://doi.org/10.1016/j.culher.2017.02.009 
Ballaney, Shirley, (2008). The Town Planning Mechanism in Gujarat, India/ The International Bank for Reconstruction and Development /USA: The World Bank Washington, D.C. 20433

Battley, Belinda, Authenticity in places of belonging: community collective memory as a complex, adaptive recordkeeping system, https:// doi.org/ $10.1080 / 01576895.2019 .1628649$

Bewley, Robert, (2014). Heritage and Economy: Perspectives from Recent Heritage Lottery Fund Research, Volume 13, 2014 - Issue 1-3: Archaeology

and Economic Development Pages 240-249 | Published online: 16 Dec 2014

Bowitz, Einar, et.al. (2009). Economic impacts of cultural heritage - Research and perspectives, Journal of Cultural Heritage: Volume 10, Issue 1, JanuaryMarch 2009, Pages 1-8

Bueno, Christopher F., The Best Practice of Public Administration in the Cultural Conservation and Management of the UNESCO Heritage City of Vigan,

University of Northern Philippines, 2010

Cabañero, Isaiah S. \& Coloma IV, Cecilio, Iloilo City Cultural Heritage Conservation Council Conservation Planning and Development for Iloilo Heritages Structure and Sites, University of the Philippines, Diliman, May 23, 2017

Chias, Pilar, (2012). Colonial Urban Planning and Land Structures in the Philippines, 1521- 1898. University of Alcala: 18.55 researhgate.net/ publication/267337493

COAWEB Center ICTC Cultural Museum Bulacan Copyright 2000.

Conceptualizing a sustainable Development Model for Cultural Heritage Tourism in Asia, School of Housing Building and Planning, University of Sains Malaysia, 118000 Pulau Pinang, Malaysia, 2019

DeSilvey, Caitlin, et.al. (2019). Anticipating loss: rethinking endangerment in heritage futures, https://doi.org/10.1080/13527258.2019.1644530

Flores, Patrick D. (2010). Intangible Cultural Heritage in the Philippines: A State of the Knowledge Report on Safeguarding, National Research Institute for Cultural Properties, Tokyo, International Seminar: Published on 5 March 2010

Friedrichs, Jurgen, A Theory of Urban Decline: Economy, Demography and Political Elites, Urban Studies, Sage Publications, Ltd., 1993

Gentry, Kynan, et.al.,Critical heritage studies and the leagcies of the late-twentieth century heritage canon, https://doi.org./10.1080/13527258.2019.1570964

Henderson, Joan, (2017). Conserving Heritage in South East Asia: Cases from Malaysia Singapore and the Philippines, Nanyang Technology University, DOI: $10.1080 / 0250281.2012 .11081687$

Hubbard, Phil, et.al., Selling the Past: Heritage-tourism and Place Identity in Stratford-upon-Avon, Geography, Geographical Association, 2000

Kita, Yuko, Contruction of house in disctrict of Santa Cruz in the City of Manila, in the 19th century, University of Tsukuba, 2009

Kumar Saikia, Budhen,(2013). Urbanization: A developmental Challenge for the third World Countries (With special reference to Assam), Global Research Methodology Journal: V01-II, 8th issue

Manasan, Ph.D., Rosario G., et.al., (1999).Governance and Urban Development: Case Study in Metro Manila, Philippine Institute for Development Study: Discussion Paper Series No. 99-03

Oscan, Koray, (2013). Protection of cultural heritage in historic towns the experience of Birgi, Pamukale University: January 2013, www.researchgate.net/publication/293303067 
Perdon, Renato, (2015). Historic Preservation in the Philippines, Munting Nayon, Protecting the Past for the Future: Proceedings of the UNESCO Regional Conferences on Historic Places, Sydney, Australia: 22-28 May 1983

Pinero, Iganacio et.al. (2017). Multi-criteria decision-making for grading rehabilitation of heritage sites. Application in the historic center of La Habana, Journal of Cultural Heritage, Vol. 26, July-August 2017, Pages 144-152/doi.org/10.1016/j.culher.2017.01.012

Pranjnawrdhi, Tri Anggrani, et.al., Landscpe Heriatge Conservation, along Sanur Beach Borderline in Bali,: Perspectives of the Local Government and Visitors, https://scinapse.io/papers/2022619009

Republic Act No. 10066 An Act Providing for the Protection and Conservation of the National Cultural Heritage, Strengthening the National Commission for Culture and the Arts (NCCA) and its Affiliated Cultural Agencies, and for Other Purposes.

Samadi, Zalina, et.al., (2012). Conflict of Image and Identity in Heritage Commercialization, Procedia: Social and Behavioral Sciences Volume 50,

2012, Pages 675-684

Se tyagung, Es tav H., et.al. (2013). Preserving Cultural Heritage: The Harmony between Art Idealism, Commercialization, and TripleHelix Collaboration: American Journal of Tourism Management 2013, 2(1): 22-28

Soraya, Mirza. (2010). Strategic Urban Planning and Design Tools for Inner City Regeneration. The Case of Bandung City, Indonesia 46th, ISOCARP: Congress 2010

Terracciano, Alda, et.al., Mapping Memory Routes: a Multisensory Interface for Sensorial Urbanism and Critical Heritage Studies, University College London, https://scinapse.io/papers/2611567753

UKessays, (2015). How cities be improved by urban design? Comment on the difficult of new project., 27th April, 2017, https://www.ukessays.com/essays/geography/urban-design- and-cities.php

UNESCO, (1073). Cultural policy in the Philippines, A study prepared under the auspice of the Unesco National Commission of the Philippines, French edition: 92-3-201133-6 [BI) SHC.73/XIX-26/A

UNESCO, Heritage City of Vigan, The Best Practice of Public Administration in the Cultural Conservation and Management of the UNESCO Heritage City of

Vigan, University of Northern Philippines, 2010

Vigan, Ilocos Sur, Heritage Conservation Program a Tool for Development, 2019

https://www.innovations.harvard.edu/heritage-conservation-program- tool-development

Wen, Jia, et. al. (2007). Stakeholder Participation Approach in Urban Cultural Heritage Management and Conservation, Cottbus, Germany: 2416754 SS 2007

Ylagan, Alex P. et.al. (2014). Tourism Studies in the Province of Batangas, Philippines: A Literature Review, International Journal of Management Sciences: Vol. 4, No. 10,421-428

Yung, Kwan Esther Hiu et.al. Sustainable Development and the Rehabilitation of a Historic Urban District-Social Sustainability in the Case of Tiangzifang in Shanghai, 2011, doi.org./10.1002/sd.534

Zhou, Xiao,et.al., 2017). Cultural investment and urban socio-economic development: a geosicial network approach, University of Cambridge.

DOI: $10.1098 / \mathrm{rsos} .170413$

\section{INTERNET}

Ahmad, A Ghafar, (2006). Cultural Heritage of Southeast Asia : Preservation for World Recognition, Journal of Malaysian Town Plan: Vol. 03, Issue 01, Jan. 2006. pg. 52-62

Artese, Maria Teresa, et. al., (2017). Evaluating perceptual visual attributes in social and cultural heritage web sites, Journal of Cultural Heritage: Volume 26, July- August 2017, Pages 91-100, 
https://doi.org/10.1016/j.culher.2017.02.009

Casocot, Ian Rosales, Temptes in a Coffee Mug, Part 5 of the Dumaguete Heritage Series, February 10, 2019

Malolos City, webpage, Malolos+City+webpage Accessed : January 2020 Malolos Historic Town Center, https://en.wikipedia.org/wiki/2018

Martinez, Melanio Jr., Facebook Page Account, demolition of Hermogenes House, February, 2020

Oscan, Koray, (2013). Protection of cultural heritage in historic towns the experience of Birgi, Pamukale University: January 2013

Pinero, Iganacio et.al. (2017). Multi-criteria decision-making for grading the rehabilitation of heritage sites. Application in the historic center of La Habana, Journal of Cultural Heritage, Vol. 26, July-August 2017, Pages

144-152/doi.org/10.1016/j.culher.2017.01.012

Setyagung, Es tav H., et.al. (2013). Preserving Cultural Heritage: The Harmony between Art Idealism, Commercialization, and TripleHelix Collaboration:

American Journal of Tourism Management 2013, 2(1): 22-28

Sembrano, Edgar Allan, Silay in Negros passes landmark heritage ordinance, Inq.Net. 03:15 AM, November 23, 2015

Sy, Joaquin, -The Malolos Heritage Town, Excerpt from the article, March 12, 2014.

The Malolos Heritage Town, Facebook Page Account, February 28, 2019

The Malolos Heritage Town, Facebook Page Account, FB post announcing the demolition of Hermogenes House in KamestizuhanMarch 10, 2014

https://www.google.com/search?q=Malolos+City+webpage\&oq=Malolos+City+ 